\title{
The relationship of fructose consumption with MDA levels in rat liver and its effect on the expression levels of COX-2 and NRF-2 genes
}

\author{
Hüseyin ÖZKAN ${ }^{1, a, ®}$, Tuncer KUTLU ${ }^{2, b}$ \\ ${ }^{1}$ Hatay Mustafa Kemal University, Faculty of Veterinary Medicine, Department of Genetics, Hatay; ${ }^{2}$ Hatay Mustafa Kemal \\ University, Faculty of Veterinary Medicine, Department of Pathology, Hatay, Turkey. \\ ${ }^{a}$ ORCID: 0000-0001-5753-8985; b ORCID: 0000-0002-8771-1256.

Corresponding author: hozkan@ $@$ mku.edu.tr
Received date: 12.11.2019 - Accepted date: 17.03.2020

\begin{abstract}
The use of fructose as converted sugar in the food industry is quite common. Steatosis and degeneration occur due to the use of fructose in the liver where sugar is primarily metabolized. However, there is not enough information about the level of MDA and the expression levels of COX-2 and NRF-2 in the liver with low and high fructose consumption. The aim of the study is to evaluate the effect of different concentrations of fructose solutions on the expression levels of COX-2 and NRF-2 genes as well as MDA levels in the livers of rats. In this study, the effects of different fructose solution [F15; (15\%) F30; (30\%) and F60; (60\%)] consumption for 10 weeks in rats on the MDA levels also COX-2 and NRF-2 genes expression levels in the liver were investigated. The MDA level and COX-2 gene expression level in F60 group were higher than the control and other groups $(\mathrm{P}<0.01)$. These findings suggest that MDA elevation in the liver may be due to inflammation. However, no change was observed in total NRF-2 gene expression. Also, a positive correlation was found between levels of COX-2 and NRF-2 expressions in F30 (0.965; P<0.01). These findings may be attributed to inflammation of liver. This may have been due to an increase in nuclear formation of NRF-2. As a result, the use of high concentration fructose solution has been found to increase the level of MDA in the liver due to inflammation.
\end{abstract}

Keywords: COX-2, fructose, gene expression, MDA, NRF-2

\section{Fruktoz tüketiminin rat karaciğerinde MDA seviyeleri ile ilişkisi ve bunun COX-2 ile NRF-2 gen ekspresyon seviyelerine etkisi}

Özet: Gıda sektöründe dönüştürülmüş şeker olarak fruktoz kullanımı oldukça yaygındır. Şekerin birincil metabolize edildiği yer olan karaciğerde fruktoz kullanımına bağlı olarak yağlanma ve dejenerasyon meydana gelmektedir. Ancak düşük ve yüksek fruktoz tüketimiyle karaciğer MDA seviyesi ile COX-2 ve NRF-2 genlerinin ekspresyon seviyeleri hakkında yeterli bilgi bulunmamaktadır. Çalışmanın amacı farklı konsantrasyonlardaki fruktoz çözeltilerinin rat karaciğerinde COX-2 ve NRF-2 gen ekspresyon seviyeleri ile MDA seviyelerine olan etkilerinin araştırılmasıdır. Bu çalışmada ratlarda farklı konsantrasyonlardaki fruktoz çözeltilerinin [F15; (\% 15) F30; (\%30) ve F60; (\%60)] 10 hafta süre tüketimiyle fruktozun karaciğerdeki MDA seviyeleri ile COX-2 ve NRF-2 gen ekspresyon seviyelerine olan etkisi araştırılmıştır. F60 grubunda MDA seviyeleri ile COX-2 gen ekspresyon seviyeleri kontrol grubu ve diğer gruplara göre yüksek bulunmuştur $(\mathrm{P}<0,01)$. Bu bulgular, karaciğerdeki MDA yüksekliğinin inflamasyona bağlı olabileceğini göstermektedir. Ancak total NRF-2 gen ekspresyonunda bir değişim gözlenmemiştir. Ayrıca, F30 grubunda COX-2 gen ekspresyon seviyesi ile NRF-2 gen ekspresyon seviyeleri arasında pozitif korelasyon bulunmuştur $(0,965 ; \mathrm{P}<0,01)$. Elde edilen bulgular karaciğerdeki inflamasyon ile ilişkilendirilebilir. $\mathrm{Bu}$ durumun NRF-2'nin nükleer formasyonunun artması sonucu şekillenmiş olabileceği düşünülmektedir. Sonuç olarak yüksek doz fruktoz kullanımının inflamasyona bağlı olarak karaciğerde MDA seviyesini yükselttiği tespit edilmiştir.

Anahtar sözcükler: COX-2, fruktoz, gen ekspresyonu, MDA, NRF-2

\section{Introduction}

Fructose has been widely used as a sweetener in beverages for about 40 years. In epidemiological and experimental studies, it is stated that unnatural fructose consumption may cause hypertension, obesity, metabolic syndrome and kidney diseases $(3,20)$. Sugars have long been known to be lipogenic effect and there are more than
20 genes thought to be effective in lipogenesis $(15,19$, 26).

In addition, the structures of sugars can affect cell glycosylation. Disruption of glycolysis is a very general feature of cancer cells, and glycan structures are the best known markers for the determination of tumor aggression. In a study, it was reported that the use of fructose in cell 
culture as a carbon source increased the ability of cancer cells to metastases (16). Oxidative stress is one of the causes of cancer and defined as the disruption of the balance between free radicals and antioxidants with sweeping action in biological systems. Oxidative damage is most commonly determined by the detection of malondialdehyde (MDA) level and is considered an important marker of inflammation in the cell $(17,18)$. It was reported that even short exposure (3 days) to fructose causes oxidative stress in the Hamster Islet Tumor (HIT) cell line, which simulates hamster pancreatic $\beta$-cells (24). It was also observed that the levels of MDA increased significantly in HIT cells exposed to 100 and $200 \mathrm{mM}$ fructose for 3 days (24). However, this increase was largely initiated at the time of first exposure to fructose and thereafter a reasonable increase (at day 1, day 2 and day 3). Plasma MDA level was reported to be elevated, whereas liver antioxidant capacity was not altered in rats fed high fructose feed ( $31 \% \mathrm{w} / \mathrm{w}$ of diet) during 5 weeks trial (20).

Cyclooxygenase 2 (COX-2) enzyme is involved in various pathophysiological events including inflammation and different types of cancer. Therefore, COX-2 inhibitors are also known as an important anti-inflammatory agent $(8,21)$, since overexpression of COX-2 protein is seen as an important marker for inflammation and cancer. Sharma et al. (23) found a relationship between COX-2 protein expression and intracellular MDA levels in 5 different colon cancer cell lines (23). This finding suggests that there may be a relationship between intracellular lipid oxidation and COX-2 protein expression which is an important marker for inflammation in metabolism.

The ability of cells to maintain homeostasis during oxidative stress depends on activation or stimulation of protective enzymes. Nuclear-Factor-E2-Related Factor (NRF-2), known as an oxidative stress protective enzyme, is expressed in various tissues (14). Transcriptional activation of antioxidant genes with an antioxidant response element (ARE) is largely dependent on NRF-2. NRF-2 controls nuclear translocation in response to oxidative stress (10).

COX-2 and NRF-2 are thought to constitute oxidative equilibrium. There is literature information about oxidative damage in the cells due to fructose consumption. But, the effect of concentration has not been widely illustrated. Hence, the effect of different concentration of fructose on expression levels of COX-2 and NRF-2 genes in liver as well as MDA protein levels in rat experiment has been investigated.

\section{Material and Methods}

Animal materials and diets: The study was ethically approved by Hatay Mustafa Kemal University Animal Experiments Local Ethics Committee (2018/2-8 and
2019/06-2). Rats were housed in Experimental Research Center of Hatay Mustafa Kemal University. According to the standard conditions of the unit, the ambient light was 12 hours light, 12 hours dark (07:00-19:00 light, 19:0007:00 dark), humidity was $55 \%$ and temperature was $21 \pm 2$ ${ }^{\circ} \mathrm{C}$. Chow and water were given as ad libitum.

Four groups were formed as a control group (Con), $15 \%$ fructose solution group (F15), 30\% fructose solution group (F30) and 60\% fructose solution group (F60). Eight animals were included in each group. The body weight averages of groups were similar. The rats were approximately 8 weeks old. All groups were fed with standard chow (2600 kcal/kg ME). While Con group consumed normal drinking water, other groups (F15, F30 and F60) consumed 15\%, 30\% and 60\% fructose solution in drinking water additionally to standard chow, respectively. The standard chow ingredients were shown in Table 1.

Table 1. Standard chow ingredients

\begin{tabular}{|l|c|}
\hline Ingredients & Standard chow \\
\hline Metabolic energy $(\mathrm{kcal} / \mathrm{kg})$ & 2600.00 \\
\hline Dry matter (\%) & 88.40 \\
\hline Crude protein (\%) & 22.50 \\
\hline Crude cellulose (\%) & 8.10 \\
\hline Fat (\%) & 3.15 \\
\hline Carbohydrate (\%) & 54.72 \\
\hline Insoluble ash in $\mathrm{HCl}(\%)$ & 1.05 \\
\hline
\end{tabular}

After 10-weeks feeding period, rats were euthanized under anesthesia by taking blood from the heart. Liver tissues (L. Hepatis Dexter) of the rats were frozen immediately in liquid nitrogen and stored at $-86^{\circ} \mathrm{C}$ until total protein, MDA and gene expression analyzes of COX2 and NRF-2.

Determination of MDA levels: Approximately $5 \mathrm{~g}$ of liver tissues were taken and homogenized in PBS (Phosphate-Buffered Saline) which is 10 times as much as the liver tissues in volume. After homogenization with homogenizer (Wisd Homogenizer, HG-15D) under sterile- cold conditions, samples were centrifuged at 3000 $\mathrm{xg}$ for 10 minutes at $+4{ }^{\circ} \mathrm{C}$. Supernatants were collected into new sterile tubes. MDA levels were determined spectrophotometrically method reported by Wasowicz et al. (25). Measurements were performed on UVSpectrophotometer (Biochrom, Libra S22). Also, total protein levels were determined according to Lowry method (13). MDA levels were calculated as $\mathrm{nmol} / \mathrm{mg}$ protein.

RNA isolation and cDNA synthesis: Total RNA was isolated according to TRI-Reagent (Sigma-Aldrich, USA) kit protocol from liver tissues stored at $-86{ }^{\circ} \mathrm{C}$. 
Approximately $50 \mathrm{mg}$ tissue was used from each tissue. Samples in TRI-Reagent were homogenized under cold and sterile conditions. After chloroform, isopropyl alcohol and ethyl alcohol steps, RNA pellets were obtained. The pellets were diluted according to pellet sizes with 30-100 $\mu \mathrm{L}$ nuclease-free water. Purity (A260/280>1.70) and concentration $(>125 \mathrm{ng} / \mu \mathrm{L})$ were determined by nucleic acid meter (SMA-1000 Spectrophotometer, Merinton). RNA quality was also checked in gel electrophoresis by controlling $28 \mathrm{~S}$ and $18 \mathrm{~S}$ rRNA subunits $(100 \mathrm{~V}$ and $\sim 25$ min). Isolation was repeated from poor-quality samples.

RevertAid First Strand cDNA synthesis kit (ThermoFisher Scientific, USA) was used for cDNA synthesis. After cDNA synthesis protocol, the final volumes of the samples were completed to $150 \mu \mathrm{L}$. The thermal cycler (Biorad T100, USA) protocol was arranged for 60 minutes at $42{ }^{\circ} \mathrm{C}, 5$ minutes at $25^{\circ} \mathrm{C}$ and 5 minutes at $70{ }^{\circ} \mathrm{C}$, respectively.

Quantitative real-time PCR: COX-2 and NRF-2 genes expression levels were determined by qPCR (Biorad CFX96, USA). The qPCR protocol was 15 seconds at 95 ${ }^{\circ} \mathrm{C}, 60$ seconds at $60^{\circ} \mathrm{C}, 30$ seconds at $72{ }^{\circ} \mathrm{C}$ and 40 cycles after $10 \mathrm{~min}$ denaturation at $95{ }^{\circ} \mathrm{C}$. All samples were studied duplicate in qPCR. PPIA (Peptidylprolyl isomerase A - Cyclophilin A) was used as the reference gene for internal control. The products obtained from qPCR were controlled by melting curve and gel electrophoresis analysis. Information about the primers used for amplification is given in Table 2.

Statistical analysis: SPSS 22.0 package program by IBM was used for statistical analysis. One-way analysis of variance and Duncan's multiple comparison test were used to determine the effect of fructose consumption on MDA levels in the liver. $\mathrm{Ct}$ values of the COX-2 and NRF-2 genes obtained from qPCR were normalized according to the reference gene and calculated as fold change with the $2^{-\Delta \Delta C t}$ method (12). On the other hand, Pearson Correlation test was used to determine the relationship between MDA levels and expression levels of COX-2 and NRF-2.

\section{Results}

In F60 group, MDA level was $7.95 \pm 0.85 \mathrm{nmol} / \mathrm{mg}$ protein. This result was significantly higher than those of control, F15 and F30 groups ( $\mathrm{P}<0.01)$. Liver tissues MDA levels in groups were given in Table 3.

Purity (A260/280) of the total RNA isolated from liver tissues was $1.94 \pm 0.02$ and the concentration was $322.57 \pm 26.02 \mathrm{ng} / \mu \mathrm{L}$. In F15 and F30, liver COX-2 gene expression levels were $1.49 \pm 0.57$ and $1.91 \pm 0.91$, respectively. However, COX-2 gene in F60 were approximately 5 folds $(4.86 \pm 1.70)$ upregulated $(\mathrm{P}<0.05)$. On the other hand, NRF-2 gene expression level was $0.91 \pm 0.15 ; 1.29 \pm 0.37$ and $1.64 \pm 0.66$ in F15, F30 and F60, respectively (Table 3 , Figure 1 ).

Correlations between liver MDA levels and COX-2, NRF-2 gene expression levels were shown in Table 4. There was a significant negative correlation between NRF-2 in the control and MDA levels in the F30 group (0.801; $\mathrm{P}<0.05)$. Furthermore, a positive correlation was found between MDA in the Con and COX-2 expression level in the $\mathrm{F} 60$ ( 0.819 ; $\mathrm{P}<0.05)$. In addition, a significant positive correlation was found between $\mathrm{COX}-2$ and NRF2 genes expression levels in F30 (0.965; P<0.01).

Table 2. Primer sequences of the genes

\begin{tabular}{llcc}
\hline Genes & Forward and Reverse Primer Sequences & Product Length & References \\
\hline \multirow{2}{*}{ PPIA } & F: 5'-CAGACAAAGTTCCAAAGACAGCA-3 & 117 & 22 \\
& R: 5'-CACCCTGGCACATGAATCCT-3' & & 7 \\
COX-2 & F: 5'-TGTATGCTACCATCTGGCTTCGG-3' & 94 & 7 \\
& R: 5'-GTTTGGAACAGTCGCTCGTCATC-3' & & 7 \\
NRF-2 & F: 5'-TTGTAGATGACCATGAGTCGC-3' & 141 & 7 \\
\hline
\end{tabular}

F: Forward, R: Reverse

Table 3. MDA and gene expression levels of COX-2 and NRF-2 in liver $(\bar{X} \pm S \bar{x})$

\begin{tabular}{cccccc}
\hline \multirow{2}{*}{ Parameters } & \multicolumn{5}{c}{ Groups } \\
\cline { 2 - 5 } & Con & F15 & F30 & F60 & P \\
\hline MDA (nmol/mg protein) & $5.86 \pm 0.41^{\mathrm{a}}$ & $4.55 \pm 0.62^{\mathrm{a}}$ & $5.07 \pm 0.58^{\mathrm{a}}$ & $7.95 \pm 0.85^{\mathrm{b}}$ & $<0.01$ \\
COX-2 & $1.00 \pm 0.12$ & $1.49 \pm 0.57^{\mathrm{a}}$ & $1.91 \pm 0.91^{\mathrm{a}}$ & $4.86 \pm 1.70^{\mathrm{b}}$ & $<0.05$ \\
NRF-2 & $1.00 \pm 0.18$ & $0.91 \pm 0.15$ & $1.29 \pm 0.37$ & $1.64 \pm 0.66$ & $>0.05$ \\
\hline
\end{tabular}

a,b: Means with different letters in rows differ significantly $(\mathrm{P}<0.05)$ 


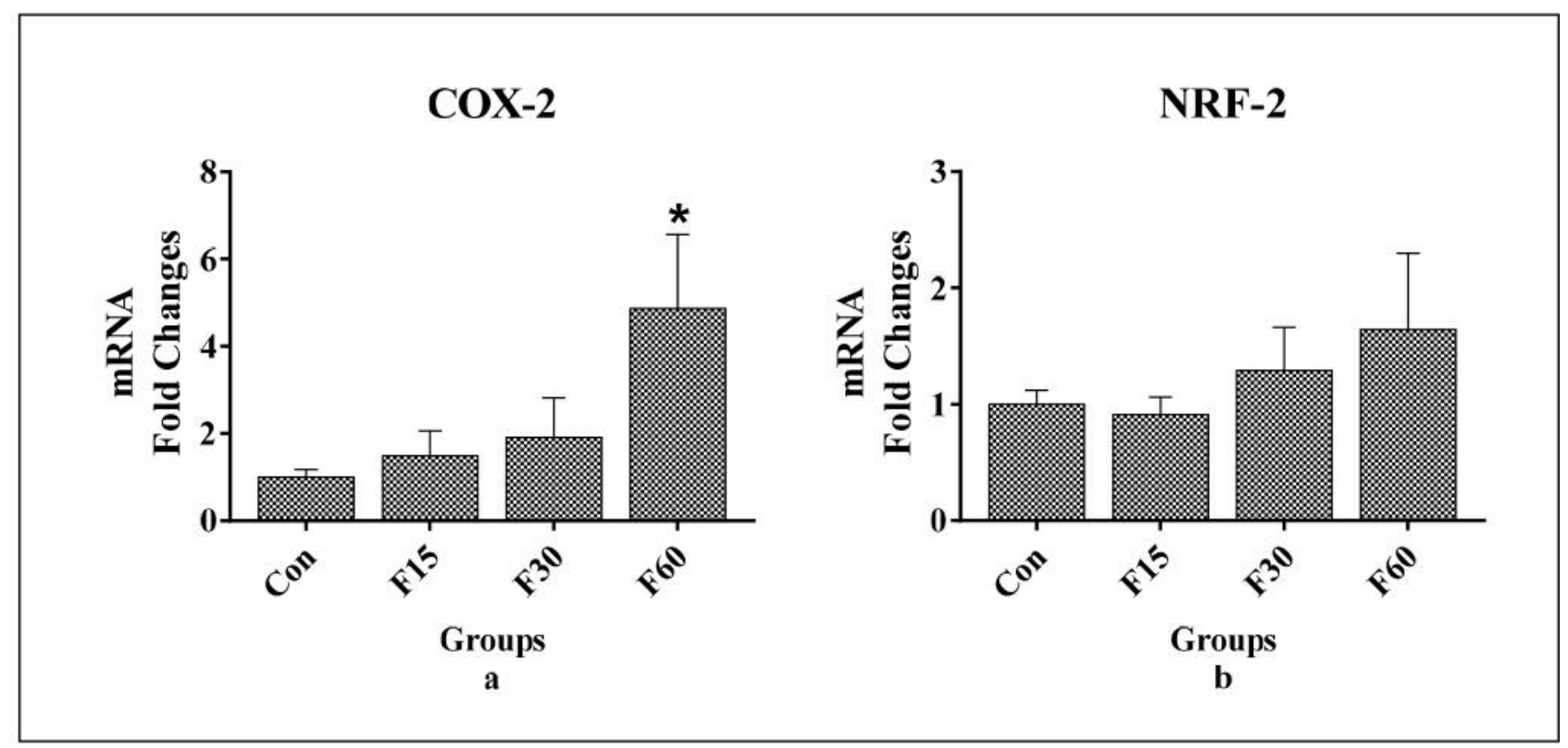

Figure 1. a) COX-2 gene expression levels in groups, b) NRF-2 gene expression levels in groups.

Table 4. Correlation coefficients between liver MDA level and expression levels of COX-2 and NRF-2 genes

\begin{tabular}{|c|c|c|c|c|c|c|c|c|c|c|}
\hline & & \multicolumn{3}{|c|}{ F15 } & \multicolumn{3}{|c|}{ F30 } & \multicolumn{3}{|c|}{ F60 } \\
\hline & & MDA & COX-2 & NRF-2 & MDA & COX-2 & NRF-2 & MDA & COX-2 & NRF-2 \\
\hline \multirow{3}{*}{ Con } & MDA & 0.521 & 0.625 & 0.236 & -0.448 & 0.281 & 0.296 & -0.529 & 0.819* & -0.017 \\
\hline & $\mathrm{COX}-2$ & 0.214 & -0.279 & -0.211 & -0.492 & -0.209 & -0.204 & 0.063 & -0.258 & -0.558 \\
\hline & NRF-2 & 0.400 & 0.084 & -0.437 & $-0.801 *$ & -0.314 & -0.235 & -0.075 & -0.513 & -0.246 \\
\hline \multirow{3}{*}{ F15 } & MDA & - & -0.765 & 0.566 & -0.215 & -0.180 & -0.216 & 0.293 & -0.303 & -0.085 \\
\hline & $\mathrm{COX}-2$ & & - & 0.004 & -0.373 & 0.438 & 0.642 & -0.633 & -0.438 & 0.554 \\
\hline & NRF-2 & & & - & 0.138 & $0.854 *$ & 0.719 & -0.394 & 0.087 & 0.771 \\
\hline \multirow{3}{*}{ F30 } & MDA & & & & - & $-0,102$ & -0.156 & -0.320 & -0.779 & -0.163 \\
\hline & $\mathrm{COX}-2$ & & & & & - & $0.965 * *$ & -0.534 & -0.300 & -0.087 \\
\hline & NRF-2 & & & & & & - & -0.584 & -0.426 & 0.089 \\
\hline \multirow{3}{*}{ F60 } & MDA & & & & & & & - & 0.783 & 0.129 \\
\hline & COX-2 & & & & & & & & - & -0.514 \\
\hline & NRF-2 & & & & & & & & & - \\
\hline
\end{tabular}

$*: \mathrm{P}<0.05 ; * *: \mathrm{P}<0.01$

\section{Discussion and Conclusion}

As a result of the glycation reactions from the degradation of sugars, Reactive oxygen species (ROS) are produced. Fructose, a strong sugar degradation product, was found to increase lipid peroxidation in the F60 group's rats liver. In a study, it has also been stated that MDA levels increase in the hamster pancreatic $\beta$-cell line as a result of lipid peroxidation due to fructose exposure (24). It was reported that MDA may increase due to many factors such as smoking, diabetes, inflammation, toxicity, exposure to mutagens and stress (2). In this study, it was determined that the increase of MDA level in the F60 was accompanied by the upregulated COX-2 gene expression level. The COX-2 upregulated approximately 5 folds in the F60 compared to control. These findings show that inflammation is the main factor for the increase of MDA levels by the consumption of high concentrations of fructose. Also, studies have shown that COX-2 gene expression levels increase due to inflammation $(9,23)$. In this study, it was determined that there were no significant changes in the F15 and F30 groups in terms of MDA levels compared to the control group. In a study, it was stated that feeding the rats with $18 \%$ fructose for 8 weeks had led no any changes of SOD and GSH-Px values in liver (6). This indicates that lipid peroxidation, which is expected to occur in the liver when using fructose, depends on the exposure time or concentration.

Due to high fructose consumption in F60, it is expected to upregulation of NRF-2 which coding antioxidant enzyme. However, Pasko et al. (20) studied 
with rats consumed $31 \%$ fructose for 5 weeks and reported that although MDA levels of plasma increased, the antioxidant capacity of the liver did not change (20). In this study, there was no change in expression levels of NRF-2 in liver consistent with Pasko et al. (20) findings. Although there was an increase in the level of MDA due to the use of fructose, it was thought to be insufficient to stimulate antioxidant capacity. In a study, it was reported that due to fructose consumption, MDA levels and cellular NRF-2 formation increased, but it was not detected changes in total NRF-2 formation (27). The NRF-2 gene, on the other hand, has a very different function than stimulation of antioxidant capacity, such as autophagy, apoptosis, ER stress, proteasomal protein degradation, cell proliferation, and metabolic programming. It is even involved in opposing metabolic reactions (14). An effect on these mechanisms may lead to a change in the role of NRF-2 on the antioxidant mechanism. Therefore, other mechanisms need to be examined in order to evaluate the relationship between NRF-2 and MDA. Since there is more than one pathway that affects one gene, experiments should be conducted that cover as many other pathways as possible. The information obtained from these experiments should be evaluated together.

The correlation between MDA level, COX-2 and NRF-2 gene expression levels were examined. It was found that there was a high significant positive correlation between expression levels of COX-2 in F60 and MDA levels in control $(0.819 ; \mathrm{P}<0.05)$. This correlation also supported their own averages of the related values (Table 3). This finding confirmed that increased MDA levels in the livers of rats consumed $60 \%$ fructose (F60) was due to inflammation detected by COX-2 gene expression level. Another high and significant positive correlation was found between the expression level of COX-2 and NRF-2 genes in the F30 $(0.965 ; \mathrm{P}<0.01)$. However, this effect disappeared in the F60. It was thought that NRF-2 acts with COX-2 gene expression level up to a certain concentration of consumed fructose in drinking water, but this effect disappears when the concentration of consumed fructose increases. It was stated that the reaction to fructose in metabolism varies according to the amount and duration of exposure $(1,4,6)$. There was no significant relationship between MDA level and COX-2, NRF-2 gene expression other than the 2 above mentioned. The effect of multiple pathways in metabolism on related variables was thought to be the cause of these results. The COX-2 gene is mainly active in inflammation and prostaglandin synthesis but is also involved in a wide range of metabolic processes such as cell proliferation $(5,9)$. The NRF-2 gene is mainly involved in ROS production in the PI3K-AKT signaling pathway, on the other hand, it can also act on MAPK and apoptosis signaling pathways (11).
As a result, the use of high concentrations of fructose increased COX-2 gene expression in the liver, resulting in an increase in inflammation-related MDA level. Also, a high and significant positive correlation was found between the COX-2 expression in the F60 and the MDA level in the Control. Some of the genes play active roles in the emergence of a character, while others work together with many pathways for the formation of a character.

\section{Financial Support}

This study was financially supported by TUBITAK (1180381).

\section{Ethical Statement}

This study was approved by the Hatay Mustafa Kemal University Animal Experiments Local Ethics Committee (2018/2-8 and 2019/06-2).

\section{Conflict of Interest}

The authors declared that there is no conflict of interest.

\section{References}

1. Batista LO, Ramos VW, Rosas Fernández MA, et al (2019): Oral solution of fructose promotes SREBP-1c highexpression in the hypothalamus of Wistar rats. Nutr Neurosci, 22, 648-654.

2. Bhutia Y, Ghosh A, Sherpa ML, et al (2011): Serum malondialdehyde level: Surrogate stress marker in the Sikkimese diabetics. J Nat Sc Biol Med, 2, 107-112.

3. Bulut İK, Mir S (2011): Fruktoz ve böbrek hastalıkları. CMJ, 33, 499-507.

4. de Moura RF, Ribeiro C, de Oliveira JA, et al (2008): Metabolic syndrome signs in Wistar rats submitted to different high-fructose ingestion protocols. Br J Nutr, 101, 1178-1184.

5. Frungieri MB, Weidinger S, Meineke V, et al (2002): Proliferative action of mast-cell tryptase is mediated by PAR2, COX2, prostaglandins, and PPAR : possible relevance to human fibrotic disorders. Proc Natl Acad Sci, 99, 15072-15077.

6. Girard A, Madani S, El Boustani ES, et al (2005): Changes in lipid metabolism and antioxidant defense status in spontaneously hypertensive rats and Wistar rats fed a diet enriched with fructose and saturated fatty acids. Nutrition, 21, 240-248.

7. Güvenç M, Cellat M, Özkan H, et al (2019): Protective effects of tyrosol against DSS-induced ulcerative colitis in rats. Inflammation, 42, 1680-1691.

8. Harper KA, Tyson-Capper AJ (2008): Complexity of COX-2 gene regulation. Biochem Soc Trans, 36, 543-545.

9. Kaliman P, Álvarez-López MJ, Cosín-Tomás M, et al (2014): Rapid changes in histone deacetylases and inflammatory gene expression in expert meditators. Psychoneuroendocrinology, 40, 96-107.

10. Kang KW, Lee SJ, Kim, SG (2005): Molecular mechanism of nrf2 activation by oxidative stress. Antioxid. Redox Signal, 7, 1664-1673. 
11. Kegg Pathway (2019): Fluid shear stress and atherosclerosis Available at https://www.genome.jp/keggin/show_pathway?map=hsa05418\&show_description=sho w (Accessed Nov 6, 2019)

12. Livak KJ, Schmittgen TD (2001): Analysis of relative gene expression data using real-time quantitative PCR and the $2^{-\triangle \triangle C T}$ method. Methods, 25, 402-408.

13. Lowry OH, Rosebrough NJ, Farr AL, et al (1951): Protein measurement with the folin phenol reagent. JBC, 193, 265-275.

14. Ma Q (2013): Role of nrf2 in oxidative stress and toxicity. Annu Rev Pharmacol, 53, 401-426.

15. Miyazaki M, Dobrzyn A, Man WC, et al (2004): StearoylCoA desaturase 1 gene expression is necessary for fructosemediated induction of lipogenic gene expression by sterol regulatory element-binding protein-1c-dependent andindependent mechanisms. J Biol Chem, 279, 25164-25171.

16. Monzavi-Karbassi B, Hine RJ, Stanley JS, et al (2010): Fructose as a carbon source induces an aggressive phenotype in MDA-MB-468 breast tumor cells. Int J Oncol, 37, 615-622.

17. Nakkeeran M, Priasamy S, Inmozhi SR, et al (2017): Increased levels of inflammatory marker hSCRP, MDA and lipid profile in non-obese hypertension subjects. Biochem Anal Biochem, 6, 2161-2165.

18. Özcan O, Erdal H, Çakırca G, et al (2015): Oksidatif stres ve hücre içi lipit, protein ve DNA yapıları üzerine etkileri. JCEI, 6, 331-336.

19. Özkan H, Yakan A (2019): Dietary high calories from sunflower oil, sucrose and fructose sources alters lipogenic genes expression levels in liver and skeletal muscle in rats. Ann Hepatol, 18, 715-724.

20. Pasko P, Barton H, Zagrodzki P, et al (2010): Effect of diet supplemented with quinoa seeds on oxidative status in plasma and selected tissues of high fructose-fed rats. Plant Food Hum Nutr, 65, 146-151.

21. Roelofs HM, Te Morsche RH, van Heumen BW, et al (2014): Over-expression of COX-2 mRNA in colorectal cancer. BMC Gastroenterol, 14, 1-6.

22. Santos BPd, da Costa Diesel LF, da Silva Meirelles L, et al (2001): Identification of suitable reference genes for quantitative gene expression analysis in rat adipose stromal cells induced to trilineage differentiation. Gene, 594, 211219.

23. Sharma RA, Gescher A, Plastaras JP, et al (2001): Cyclooxygenase-2, malondialdehyde and pyrimidopurinone adducts of deoxyguanosine in human colon cells. $\mathbf{J}$ Carcinog, 22, 1557-1560.

24. Suzuki K, Islam KN, Kaneto $\mathbf{H}$, et al (2000): The contribution of fructose and nitric oxide to oxidative stress in hamster islet tumor (HIT) cells through the inactivation of glutathione peroxidase. Electrophoresis: Int J, 21, 285288.

25. Wasowicz W, Neve J, Peretz A (1993): Optimized steps in fluorometric determination of thiobarbituric acid-reactive substances in serum: importance of extraction $\mathrm{pH}$ and influence of sample preservation and storage. Clin Chem, 39, 2522-2526.

26. Zhang H, Li Y, Hu J, et al (2015): Effect of creosote bushderived NDGA on expression of genes involved in lipid metabolism in liver of high-fructose fed rats: relevance to NDGA amelioration of hypertriglyceridemia and hepatic steatosis. PLoS One, 10, 1-21.

27. Zhang HF, Shi LJ, Song GY, et al (2013): Protective effects of matrine against progression of high-fructose dietinduced steatohepatitis by enhancing antioxidant and antiinflammatory defences involving Nrf2 translocation. Food Chem Toxicol, 55, 70-77. 